\title{
SELECTING ANTICOAGULATION REGIMEN TO FIT THE PREGNANCY IN WOMEN WITH MECHANICAL CARDIAC VALVULAR PROSTHESES
}

\author{
ANCA A. SIMIONESCU ${ }^{1 *}$, ALI SAPHIA ${ }^{2}$, MIRCEA CINTEZĂ $^{3}$, ALEXANDRU FILIPESCU $^{2}$ \\ I "Carol Davila” University of Medicine and Pharmacy, Department of Obstetrics and Gynaecology, Filantropia Hospital, \\ Bucharest, Romania \\ 2 "Carol Davila" University of Medicine and Pharmacy, Department of Obstetrics and Gynaecology, Elias Emergency \\ Hospital, Bucharest, Romania \\ 3 "Carol Davila” University of Medicine and Pharmacy, Department of Cardiology, University Emergency Hospital, \\ Bucharest, Romania
}

*corresponding author: asimion2002@yahoo.com

Manuscript received: October 2020

\begin{abstract}
Advances in cardiovascular surgery and postoperative care make pregnancy possible for women with cardiac valvular prostheses due to impacts on maternal survival rates. However, mechanical cardiac valvular prostheses represent a high risk for increased maternal mortality and morbidity due to haemorrhage, heart failure, valvular thrombosis, and maternal thromboembolism events throughout pregnancy. It remains challenging to select an anticoagulation regimen that is safe and effective during the pregnancy and postpartum periods. Foetal risks include the teratogenic effects of medications; intracranial haemorrhage; intrauterine growth restriction, which results in a child small for its gestational age at birth; prematurity; and intrauterine foetal death. Vaginal delivery is recommended, after adapting an anticoagulant therapy. Caesarean sections might be considered for obstetric reasons or for patients at high risk for hemodynamic instability or valve thrombosis, or in patients taking warfarin. In this review, we provide a pregnancy-centred framework to assist clinicians in recommending the right anticoagulation regimen therapy for the management of pre-existing valvular pathology-associated pregnancies. A therapeutic anticoagulation schedule may improve both maternal and foetal outcomes. Moreover, a contraindication for pregnancy exists in the presence of severe mitral or aortic diseases or a mechanical valvular prosthesis when effective anticoagulation is not possible.
\end{abstract}

\section{Rezumat}

Datorită dezvoltării chirurgiei cardiovasculare și îmbunătățirii îngrijirilor postoperatorii cu creșterea ratei de supraviețuire, sarcina este posibilă la pacientele purtătoare de valve mecanice cardiace. Totuşi, valvele mecanice cardiace reprezintă un factor de risc pe parcursul sarcinii, care se asociază cu creșterea mortalității și morbidității materne prin hemoragie, insuficiență cardiacă, tromboză valvulară și accidente tromboembolice materne. Alegerea schemei de tratament anticoagulant sigur și cu cele mai puține complicații în sarcină și postpartum rămâne o mare provocare. Riscurile fetale includ efectul teratogenic al medicației, hemoragia intracraniană, restricția de creștere intrauterină și feți mici pentru vârsta de gestație la naștere, prematuritatea şi moartea fetală intrauterină. Se recomandă naşterea pe cale vaginală după adaptarea terapiei anticoagulante la aceste paciente. Pentru indicații obstetricale sau în cazul pacientelor cu risc crescut de tromboză valvulară, instabilitate hemodinamică sau aflate sub terapie cu warfarină, se indică nașterea prin operație cezariană. Scopul acestui review este să prezinte scheme terapeutice de anticoagulante în sarcină, utile pentru clinicianul care trebuie să le recomande gravidelor purtătoare de valve mecanice cardiace. Utilizarea tratamentului anticoagulant adaptat sarcinii pare să îmbunătățească prognosticul matern și fetal. Totuși, sarcina este contraindicată pacientelor cu leziuni valvulare severe aortice sau mitrale sau la cele cu valve mecanice cardiace la care tratamentul anticoagulant nu este eficient.

Keywords: anticoagulation, cardiac valvular prosthesis, management, pregnancy, thromboembolism

\section{Introduction}

Cardiovascular pathologies comprise an important public health problem. They occur in an estimated 1 $4 \%$ of pregnancies [8]. Maternal survival rates have increased among pregnant women with cardiac valvular prostheses, mainly due to advances in diagnostics, treatment, and follow-ups for valvular heart disease. Although mortality during pregnancy is a relatively rare occurrence, pregnancy is a serious mortality risk factor in women with cardiac valvular prostheses, due to haemorrhage, valvular thrombosis, medications, and thromboembolism. International guidelines suggest that less thrombogenic biological valves should be considered in women that desire to become pregnant $[12,16,24,30,32]$. Compared to mechanical valves, bioprosthetic valves require replacement more often, particularly in younger patients. After 10 years, 82\% 
of bioprosthetic valves require replacement [7, 17]. Among women that are around 20 years of age when implanted, there is a $90 \%$ risk of re-intervention within the first 15 - 20 years after implantation, due to a structural dysfunction [7, 17]. In contrast, most mechanical valves have the advantage of superior hemodynamic profiles and durability. However, their use is associated with a life-long need of effective anticoagulation and a high risk of thrombotic events. The reported maternal death rate among women with mechanical valves is around $15 \%$, according to a review by Chan et al. [4]. Anticoagulation treatment is critical for the prevention of thromboembolic events. However, adequate anticoagulation regimens are imperative during pregnancy in patients with valvular cardiac prostheses. Non-pregnant women with mechanical cardiac valvular prostheses receive treatment with vitamin $\mathrm{K}$ antagonists (VKAs), but these drugs increase risk for the foetus, including their intrinsic teratogenic effect. Depending on the foetus stage of development and the dose of drug, alternative anticoagulation regimens have been proposed in pregnancy. Until recently, VKAs, such as oral warfarin; unfractionated heparin (UFH, parentally); or low-molecular-weight heparin (LMWH), such as subcutaneous enoxaparin or dalteparin, have been widely used during pregnancy associated thrombosis and cardiovascular disease $[12,24]$. Foetal and neonatal side-effects of these medications administered during pregnancy include intracranial haemorrhage, intrauterine growth restriction, which leads to a small foetus for its gestational age, prematurity and intrauterine death. These infants often require hospitalization and life-long care, which increases the costs to the family and the health care system. Preconception counselling, anticoagulation medication should be discussed with the patient to provide information about maternal and foetal risks. This review aimed to provide a pregnancy-centred framework to assist clinicians in recommending the right anticoagulation regimen therapy for the management of pre-existing mechanical cardiac valvular prostheses associated pregnancies, based on the scientific literature published in the period $2000-2019$.

\section{Haemodynamics of pregnancy}

The major pregnancy-related hemodynamic change is to cardiac output, which substantially increases from 6 weeks of pregnancy with an average increase in blood volume of 50\% $[9,19]$ and a concomitant decrease in blood pressure, as well as systemic vascular resistance. The glomerular filtration rate also begins to increase by 6 weeks, with a peak of values by 14 weeks. In the third trimester, glomerular filtration rates decrease and return of the filtration fraction to a prepregnancy value of $1 / 5$ [3]. In the second trimester, the haemoglobin concentration falls (physiological anaemia). Normal pregnancy includes a hypercoagulation state, which features increases in fibrinogen and most coagulation factors. Additionally, the procoagulant state causes an increase in the prothrombin time (PT) according to the international normalized ratio (INR), with a decrease in the activated partial thromboplastin time (aPTT) $[12,19]$. These changes contribute to physiological haemostasis during delivery, which consumes blood coagulation factors and platelets. During contractions, oxygen consumption is increased and both systolic and diastolic blood pressure rise. A temporary increase in cardiac pressure can occur in the immediate postpartum period due to compression of the inferior vena cava being relieved and the significant increase in blood volume despite blood loss $(500 \mathrm{~mL}$ normal during normal labour or $1000 \mathrm{~mL}$ normal blood loss during Caesarean section). These changes might lead to clinical deterioration. In cases of pre-existing heart disease, intolerance to these changes can cause foetal and maternal morbidity and mortality $[9,12]$.

\section{Choosing anticoagulant therapy during pregnancies associated with mechanical valve prostheses}

When mechanical valve prostheses are present during pregnancy, systematic anticoagulant therapy is given, with the objective of preventing valve thrombosis and thromboembolic events - the main causes of maternal mortality $[2,6,13,14,16,20,25]$. There is not a standard protocol for the optimal anticoagulant prescription during pregnancy. The present recommendations are based on guidelines provided by the American Heart Association Task Force, American College of Cardiology, European Society of Cardiology, and the Romanian Society of Obstetrics and Gynaecology (SOGR), and from clinical recommendations in randomized trials or meta-analysis $[16,24,39]$. The following anticoagulation methods are used in pregnant women who have mechanical cardiac valvular prostheses: VKAs, UFH, or LMWH throughout pregnancy or sequential treatments involving, for example, VKAs for 35 weeks followed by UFH or LMWH; UFH for 12 weeks followed by VKAs to 35 weeks then by LMWH; UFH administered parentally for the first trimester, and then oral VKAs in subsequent trimesters $[3,31]$. New oral anticoagulants (danaparoid, hirudin, argatroban and fondaparinux) are not used in pregnancy due to limited data about their safety [34]; there are congenital anomalies, growth restricted foetus cases reported when administered [28].

The first-generation prosthetic heart valves, such as Starr-Edwards or Björk-Shiley, are considered highrisk maternal complication compared to the secondgeneration St-Jude Medical prosthetic heart valves $[3,7]$. The position of the mechanical valve, the type of valve, and existing maternal cardiac complications (flutter or atrial fibrillation) determine the risk of valve thrombosis. This risk appeared to be lowest among 
FARMACIA, 2021, Vol. 69, 2

mothers that used vitamin-K-antagonists (VKAs) (4\%) and it increased with the use of unfractionated heparin (UFH) [4]. When warfarin treatments were changed to UFH, $50 \%$ of mechanical valve thromboses occurred in the first trimester of pregnancy [35]. It is a legitimate concern that anticoagulant treatments during pregnancy might increase the hemorrhage and embryo-fetotoxicity risks. A previous review estimated that the risk of maternal hemorrhage was $2.5 \%$ among women that received anticoagulants, and most episodes
(80\%) occurred in association with delivery [4]. In 2018 , a study investigated anticoagulation regimens in women who have mechanical valve prostheses using the Registry of Pregnancy and Cardiac Diseases (ROPAC) [27]. Table I shows the anticoagulation regimens used during pregnancies associated with mechanical valvular prostheses. These regimens included VKAs, warfarin, UFH, and LMWH based on actual recommendations $[11,15,16,25,26,31]$.

Table I

Anticoagulation regimens during pregnancies associated with mechanical valvular prostheses

\begin{tabular}{|c|c|}
\hline Pre-pregnancy & - VKA (warfarin) derivatives until pregnancy \\
\hline $\begin{array}{l}\text { First trimester } \\
\text { (6 - } 12 \text { weeks) }\end{array}$ & $\begin{array}{l}\text { - If daily dose }<5 \mathrm{mg} \text { warfarin or }<2 \mathrm{mg} \text { acenocoumarol, continue coumarin derivative } \\
\text { adjusted to standard INR } \\
\text { - If daily dose greater than those limits, substitute twice daily subcutaneous LMWH dose } \\
\text { (peak anti-Xa } 4 \mathrm{~h} \text { post-dose, } 0.7 \text { to } 1.2 \mathrm{U} / \mathrm{mL} \text { ) } \\
\text { - However, if peak levels are therapeutic but trough levels sub-therapeutic, dose three times } \\
\text { daily } \\
\text { - Weekly check of anti-Xa } \\
\text { - If LMWH is unavailable, consider UFH, given at doses to maintain an aPTT) of 2- to } 2.5 \text { - } \\
\text { fold above control }\end{array}$ \\
\hline $\begin{array}{l}\text { Second and third trimester } \\
(13-35 \text { weeks })\end{array}$ & $\begin{array}{l}\text { - OAC (warfarin) derivative, dosed to achieve standard INR }(2.5-3.5) \\
\text { - Otherwise, twice daily subcutaneous LMWH at an adjusted dose (peak anti-Xa } 4 \text { h post- } \\
\text { dose, } 1.0 \text { to } 1.2 \mathrm{U} / \mathrm{mL} \text { ) }\end{array}$ \\
\hline 36 weeks and later & $\begin{array}{l}\text { - Substitute coumarin derivative with twice daily subcutaneous LMWH (target anti-Xa } 4 \text { - } 6 \mathrm{~h} \\
\text { post-dose, } 1.0 \text { to1.2 } \mathrm{U} / \mathrm{mL} \text { ) } \\
\text { - or substitute coumarin with intravenous UFH, dosed to achieve an aPTT } 2 \text { - to } 2.5 \text {-fold } \\
\text { above control } \\
\text { - Adjust the LMWH dose for peak anti-Xa } 4 \mathrm{~h} \text { post-dose }(0.7 \text { to } 1.2 \mathrm{U} / \mathrm{mL}) \\
\text { - If peak levels are therapeutic but trough levels sub-therapeutic, dose three times daily } \\
\text { - Weekly check of anti-Xa }\end{array}$ \\
\hline Delivery & $\begin{array}{l}\text { - Stop UFH } 4 \text { - } 6 \mathrm{~h} \text { prior } \\
\text { - Stop LMWH } 12-24 \mathrm{~h} \text { prior }\end{array}$ \\
\hline Postpartum period & $\begin{array}{l}\text { - If no bleeding occurs, start prophylactic intravenous UFH after } 6 \mathrm{~h} \text {, or subcutaneous LMWH, } \\
\text { and gradually increase the dose to achieve therapeutic anticoagulation over } 24 \text { to } 48 \mathrm{~h} \\
\text { - After } 7 \text { - } 10 \text { days, UFH or LMWH should be switched to OAC }\end{array}$ \\
\hline
\end{tabular}

UFH therapy is usually restricted to use in a hospital setting to allow monitoring of the pregnant patients, including laboratory assessments to guide dosage. In the late 1980s, LMWH became more widely used because of its relative superiority to UFH, but is an expensive therapy when compared with UFH. Chan et al. reported that maternal thromboembolic events occurred in $3.9 \%$ of women that used OACs (oral anticoagulants), compared to $9.5 \%$ of women that used UFH [4]. In the ROPAC registry (2007 - 2018), valve thrombosis was recorded for $7 \%$ of patients with mechanical valves; of these, $18 \%$ died [11]. Preferably, OAC doses target an INR within the range of 0.5 units per patient. Variations in INR were associated with a high complication rate [16]. Various reviews have shown a low risk of adverse maternal complications with OAC treatment, compared to UFH or LMWH, during the first trimester [11, 15, 29, 31, 33]. However, the risks of miscarriage and late fetal death were increased when an OAC was taken in the first trimester, particularly when taken between 6 and 9 weeks of pregnancy $[15,16,26,31]$. Due to the short half-life of UFH, it is safe for pregnancy when physiological glomerular filtration rates are modified, and the anticoagulant effects are reversible under typical circumstances using protamine sulphate. Warfarin and heparin require laboratory monitoring (target INR, aPTT) and dose adjustments to ensure antithrombotic protection while minimizing the risk of haemorrhage. Because warfarin crosses the placenta, it can cause miscarriage $(15 \%$ to $56 \%$ ), embryopathy (up to $10 \%$ of cases), and major central nervous system abnormalities $(1 \%)$ during the first 6 - 12 weeks of pregnancy $[5,36]$. Most systematic reviews concluded that OACs during the first trimester present a higher foetal malformation risk $(6.4 \%)$ than heparin $(3.4 \%)[4,33]$. Several other studies demonstrated that, at 6 - 9 weeks of gestation $[26,27,31]$, warfarin is associated with teratogenicity and foetal loss $[31,33]$. Continuation of OAC is recommended before pregnancy. In addition, current evidence supports OAC use throughout pregnancy, but under strict control of the INR because OACs are considered the safest regimen, in terms of maternal risks $[15,16,25,33]$. In contrast, warfarin predisposes 
the foetus to intracranial bleeding and high rates of foetal loss [15, 33]. Consequently, warfarin use prior to delivery is an indication for a Cesarean section delivery. The long-term sequelae reported for warfarin include minor neurological dysfunctions and IQ scores below 80 [21]. Some studies demonstrated no foetal toxicity related to warfarin, but other studies have reported a high complication rate $[4,7,33]$. Continuing OAC is considered safe with daily warfarin doses below $5 \mathrm{mg}$ (acenocumarol $<2 \mathrm{mg}$, phenprocoumon $<3$ $\mathrm{mg}$ ), due to the low embryopathy risk $[11,15,22,35$, 38]. A series of studies demonstrated that the incidence of embryopathy was $2.6 \%$, when mothers took $<5 \mathrm{mg}$ warfarin daily, and it was $8 \%$, when mothers took $>5$ $\mathrm{mg}$ warfarin daily [5, 29]. Use of a VKA for anticoagulation until achieving an INR of 2.5 is recommended in patients who no risk factors other than mechanical valves. The haemorrhage risk is reduced when the INR is between 2 and $3[15,33]$.

During pregnancy, UFH additionally increases the risks of thrombocytopenia and maternal osteoporosis. The use of UFH is associated with the worst fetal and maternal outcomes [36]. Thromboembolic complications can occur, despite the use of therapeutic subcutaneous UFH [15, 26, 31, 36]. Comparing intravenous (iv) to subcutaneous (sc) therapeutic UFH administration, iv UFH might be better for preventing thromboembolism, but its efficacy and safety have not been proven satisfactory $[4,15]$.

Substituting OAC with UFH during the $6^{\text {th }}-12^{\text {th }}$ week of gestation during 6 - 12 weeks reduced the risks associated with OAC. Switching to UFH/LMWH under strict dose control during this time period can be considered in patients with low dose requirements, on an individual basis $[15,16]$.

LMWH regimens using enoxaparin and dalteparin are available in many hospitals. No teratogenic effects occur because LMWH do not cross the placenta. Fixed doses of LMWH were also associated with valve thrombosis [7, 18]. Special attention must be paid to adjusting doses according to the anti-Xa levels in order to obtain therapeutic sc LMWH [7, 10, 15, 16, $18,23,24,35,37]$. LMWH is cleared renally. As such, the increased glomerular filtration rate contributes to requiring a higher therapeutic dose during pregnancy. Throughout pregnancy, doses must be increased to

achieve and maintain a therapeutic effect. Pre-dose levels are often sub-therapeutic; the therapeutic dose of subcutaneous LMWH is adjusted to reach a target anti-Xa activity of 0.8 to 1.2 units/mL [10, 23, 37]. Using LMWH during pregnancy in women who have mechanical heart valves is currently controversial due to the few patients who have been studied and the lack of accurate data. In a recent review, the rate of valve thrombosis in 81 pregnancies (75 women) treated with LMWH was 8.6\% [18]. They concluded that appropriately adjusting the dose reduced the thromboembolism frequency. This therapeutic option was approved in clinical practice for use in pregnancy when mechanical valves are present, but their use must be limited during the first trimester. The starting dose of enoxaparin is $1 \mathrm{mg} / \mathrm{kg}$ body weight and for dalteparin $100 \mathrm{UI} / \mathrm{kg}$ body weight twice a day. This regimen can be used for patients who refuse VKAs [36]. Compared to UFH/VKAs, foetal wastage occurs significantly less with LMWH, and maternal outcomes are similar (based on a study of 2113 pregnancies) [36]. A study that included 111 pregnant women treated with an anti-Xa-adjusted dose of LMWH revealed that $9 \%$ of pregnancies developed valve thrombosis [26, 31].

When a high dose of OAC is needed, OACs can be replaced with UFH, at a dose adjusted to maintain the aPTT $\geq 2-2.5$-fold above control; or with twice daily LMWH, adjusting the dose for anti-Xa. The anti-Xa level should be as recommended within $4-6$ $\mathrm{h}$ of LMWH administration. If the regimen is refused, or LMWH is not available, OAC can be considered, after obtaining the fully informed consent.

When UFH is administered, weekly monitoring is needed. After reaching a stable aPTT $4-6 \mathrm{~h}$ after the starting dose, aPTT should be maintained at $\geq 2$ to 2.5-fold above control. Heparin is considered safe during pregnancy because it does not cross the placenta, but it is less effective in thromboprophylaxis than other drugs, particularly in the presence of metallic valve prostheses [4]. When additional risk factors are present, a VKA regimen must provide an INR of $3[11,15,26,31]$.

The estimated risks of anticoagulation therapy during pregnancy are summarized in Table II.

Table II

Estimated maternal and foetal risks of anticoagulation therapy associated with mechanical valvular heart

prostheses [1, 24, 36]

\begin{tabular}{|l|l|c|c|c|c|}
\hline & & VKAs & UFH & LMWH & VKAs + UFH \\
\hline \multirow{5}{*}{ Maternal } & Haemorrhage & $0.18-1.21 \%$ & $2.15-11.57 \%$ & $1.31-10.71 \%$ & $0.11-2.42 \%$ \\
& Death & $0.48-1.60 \%$ & $0.05-5.51 \%$ & $0.31-6.88 \%$ & $0.22-2.70 \%$ \\
& Thromboembolism & $2.01-3.84 \%$ & $19.60-42.43 \%$ & $1.64-10.52 \%$ & $4.95-10.9 \%$ \\
& Prosthetic valve thrombosis & $0-4 \%$ & $9-33 \%$ & $4.4-8.8 \%$ & - \\
\hline \multirow{2}{*}{ Foetal } & Teratogenic effect & $2.13-6 \%$ & $0-4.41 \%$ & $0-4.69 \%$ & $0.19-2.33 \%$ \\
& Foetal death & $29.65-35.55 \%$ & $41.28-65.55 \%$ & $6.76-20.78 \%$ & $18.38-27.55 \%$ \\
\hline
\end{tabular}


A prospective cohort study (1998 - 2008) that included pregnant women left-sided mechanical heart valves and were treated with LMWH reported incidences of valve thrombosis, the need to replace a valve, or stroke, during pregnancy. Among a total of 23 pregnancies, they reported 1 thromboembolic event $(4 \%)$ that caused both maternal and foetal deaths; $22 \%$ of patients developed cardiac complications; and $43 \%$ new-borns exhibited neonatal adverse effects, but nearly $50 \%$ had favourable outcomes. Postpartum haemorrhages occurred in 3 pregnancies. Valve thrombosis resulting in maternal death despite proper monitoring and maintaining anti-Xa levels at a therapeutic level highlighted the limitation of anticoagulation in this group. Nearly half of the thrombosis episodes involving prosthetic valves occurred during the first trimester, followed by a consistent percent [37].

Steinberg et al.'s meta-analysis evaluated associations between different methods of anticoagulation and foetal and maternal outcomes [33]. The overall risk associated with using VKA was $39 \%$, compared to the $13 \%$ associated with LMWH therapy. Similar results were reported for LMWH and VKA treatment (23\%) compared to UFH and VKA treatment (34\%). No significant difference was found in risk between the use of $<5 \mathrm{mg}$ warfarin and LMWH. LMWH therapy had the lowest rate of adverse foetal outcomes, whereas the risk of adverse maternal outcomes was lowest with a VKA regimen. This study reaffirmed that low-dose warfarin can be as safe as or safer than LMWH in pregnant women; these data were also supported by international guidelines [11, 38].

\section{Mode of delivery, postpartum and anticoagulation therapy}

Anticoagulant therapy should be $24 \mathrm{~h}$ before inducing labour or performing Caesarean section, UFH 4 - $6 \mathrm{~h}$ before delivery and LMWH 12 - $24 \mathrm{~h}$ before delivery. After 36 weeks gestation, warfarin should be withheld. Replacement options are UFH and LMWH.

Vaginal delivery, after spontaneous or induced labour with epidural analgesia, is recommended for women with cardiac valve prostheses. Checking the aPTT before epidural anaesthesia can obviate a spinal hematoma [11]. A caesarean section delivery with endotracheal intubation under general anaesthesia is indicated when severe cardiac symptoms occur during the latter half of the pregnancy. A caesarean section is also indicated when high valve thrombosis risk is present to ensure that VKAs are withdrawn for as short as possible times. Additionally, caesareans are indicated when onset of labour coincides with VKA treatment due to the risk of foetal intracranial bleeding. Dramatic hemodynamic alterations occur immediately postpartum, within the first 12 - 24 h [14]. Early postpartum haemorrhage can cause volume overload and fluctuations in the haemodynamics and blood pressure, with catastrophic results. Obstetric management also includes the management of fluid administration and anticoagulant-induced bleeding. Fluid management includes protamine, fresh frozen plasma, or four-factor prothrombin complex concentrate [15]. $6 \mathrm{~h}$ after delivery, anticoagulation with therapeutic enoxaparin can be initiated. Warfarin can be recommended at 5 to 7 days postpartum, at the normal pre-pregnancy doses. Prophylactic doses of subcutaneous LMWH, followed (12 $\mathrm{h}$ later) by half the therapeutic dose (based on maternal postpartum weight), can be administered twice daily [15]. One study showed that $7 \%$ of heart failures occurred within the first postpartum week [35], when hemodynamic parameters are changing.

\section{Conclusions}

Anticoagulation therapy should be closely and strictly monitored in pregnancies associated with mechanical heart valves. Studies have demonstrated the efficacy and safety of several anticoagulant regimes, when properly used. During pregnancy, hypercoagulability increases the incidence of mechanical valve thrombosis, and a multidisciplinary team should perform the followup at a tertiary centre every trimester. In women with severe mitral or aortic disease or who have a mechanical valvular prosthesis, pregnancy is contraindicated when effective anticoagulation is not possible.

VKAs administered during pregnancy increase foetal risks, but they are preferred up to 36 weeks, to reduce maternal risks. After discontinuing anticoagulants prior to delivery, maternal haemodynamic during labour, delivery, and postpartum periods should be closely monitored, being crucial for the effective haemostatic or thromboembolic events management.

\section{Conflict of interest}

The authors declare no conflict of interest.

\section{References}

1. Alshawabkeh L, Economy KE, Valente AM, Anticoagulation During Pregnancy: Evolving Strategies With a Focus on Mechanical Valves. J Am Coll Cardiol., 2016; 68(16): 1804-1813.

2. Baumgartner H, Hung J, Bermejo J, Chambers JB, Evangelista A, Griffin BP, Iung B, Otto CM, Pellikka PA, Quiñones M, American Society of Echocardiography, European Association of Echocardiography, Echocardiographic assessment of valve stenosis: EAE/ASE recommendations for clinical practice. $J$ Am Soc Echocardiogr., 2009; 22(1): 1-23.

3. Blanchard DG, Daniels LB, Cardiac disease in Creasy\&Resnik's Maternal-Fetal Medicine: principles and practice $7^{\text {th }}$ editors Robert K. Creasy, Robert Resnik, Michael F. Greene, Charles J. Lockwood, Elsevier Saunders.

4. Chan WS, Anand S, Ginsberg JS. Anticoagulation of pregnant women with mechanical heart valves: a systematic review of the literature. Arch Intern Med., 2000; 160: 191-196. 
5. Cotrufo M, De Feo M, De Santo LS, Romano G, Della Corte A, Renzulli A, Gallo C, Risk of warfarin during pregnancy with mechanical valve prostheses. Obstet Gynecol., 2002; 99(1): 35-40.

6. Detaint D, Maalouf J, Tribouilloy C, Mahoney DW, Schaff HV, Tajik AJ, Enriquez-Sarano M, Congestive heart failure complicating aortic regurgitation with medical and surgical management: a prospective study of traditional and quantitative echocardiographic markers. J Thorac Cardiovasc Surg., 2008; 136(6): 1549-1557.

7. Elkayam U, Bitar F, Valvular heart disease and pregnancy: part II: prosthetic valves. J Am Coll Cardiol., 2005; 46(3): 403-410.

8. Elkayam U, Goland S, Pieper PG, Silversides CK, High-Risk Cardiac Disease in Pregnancy: Part I. $J$ Am Coll Cardiol., 2016; 68(4): 396-410.

9. Foley M, Maternal adaptations to pregnancy: Cardiovascular and hemodynamic changes; UpToDate 2017, www.uptodate.com/contents/maternal-adaptationto-pregnancy-cardiovascular-and-hemodynamicchanges.

10. Friedrich E, Hameed AB, Fluctuations in anti-factor Xa levels with therapeutic enoxaparin anticoagulation in pregnancy. J Perinatol., 2010; 30: 253-257.

11. van Hagen IM, Roos-Hesselink JW, Ruys TP, Merz WM, Goland S, Gabriel H, Lelonek M, Trojnarska O, Al Mahmeed WA, Balint HO, Ashour Z, Baumgartner $\mathrm{H}$, Boersma E, Johnson MR, Hall R, ROPAC Investigators and the EURObservational Research Programme (EORP) Team, Pregnancy in Women with a Mechanical Heart Valve: Data of the European Society of Cardiology Registry of Pregnancy and Cardiac Disease (ROPAC). Circulation, 2015; 132(2): 132-142.

12. Hui C, Lili M, Libin C, Rui Z, Fang G, Ling G, Jianping $Z$, Changes in coagulation and hemodynamics during pregnancy: a prospective longitudinal study of 58 cases. Arch Gynecol Obstet., 2012; 285(5): 1231-1236.

13. Lindley K, Williams D, Valvular heart disease in pregnancy. Am College of Cardiology 2018, www.acc.org/latest-in-cardiology /articles /2018/02 /12/07/29/valvular-heart-disease-in-pregnancy.

14. Nanna M, Stergiopoulos K, Pregnancy complicated by valvular heart disease: an update. J Am Heart Assoc., 2014; 3(3): e00071: 1-18.

15. Nelson-Piercy C, Management of antithrombotic therapy for a prosthetic heart valve during pregnancy. Up To Date 2019; 1-24, www.uptodate.com/ contents/management-of-antithrombotic-therapyfor-a-prosthetic-heart-valve-during-pregnancy.

16. Nishimura RA, Otto CM, Bonow RO, Carabello BA, Erwin $3^{\text {rd }}$ JP, Fleisher LA, Jneid H, Mack M, McLeod CJ, O'Gara PT, Rigolin VH, Sundt $3^{\text {rd }}$ TM, Thompson A, 2017 AHA/ACC Focused Update of the 2014 AHA/ACC Guideline for the Management of patients with valvular heart disease: A report of the American College of Cardiology/American Heart Association Task Force on clinical practice guidelines. Circulation, 2017; 135(25): e1159-e1195.

17. North RA, Sadler L, Stewart AW, McCowan LM, Kerr AR, White HD, Long-term survival and valverelated complications in young women with cardiac valve replacements. Circulation, 1999; 99(20): 26692676.

18. Oran B, Lee-Parritz A, Ansell J, Low molecular weight heparin for the prophylaxis of thromboembolism in women with prosthetic mechanical heart valves during pregnancy. Thromb Haemost., 2004; 92(4): 747-751.

19. Ouzounian JG, Elkayam U, Physiologic changes during normal pregnancy and delivery. Cardiol Clin., 2012; 30(3): 317-329.

20. Pibarot P, Dumesnil JG, Doppler echocardiographic evaluation of prosthetic valve function. Heart, 2012; 98(1): 69-78

21. Pieper PG, Balci A, Van Dijk AP, Pregnancy in women with prosthetic heart valves. Neth Heart J., 2008; 16(12): 406-411.

22. Pijuan-Domènech $\mathrm{A}$, Galian L, Goya $\mathrm{M}$, Casellas $\mathrm{M}$, Merced C, Ferreira-Gonzalez I, Marsal-Mora JR, DosSubirà L, Subirana-Domènech MT, Pedrosa V, BaróMarine F, Manrique S, Casaldàliga-Ferrer J, Tornos P, Cabero L, Garcia-Dorado D, Cardiac complications during pregnancy are better predicted with the modified WHO risk score. Int J Cardiol., 2015; 195: 149-154.

23. Quinn J, Von Klemperer K, Brooks R, Peebles D, Walker F, Cohen $\mathrm{H}$, Use of high intensity adjusted dose low molecular weight heparin in women with mechanical heart valves during pregnancy: A singlecenter experience. Haematologica, 2009; 94(11): 16081612 .

24. Regitz-Zagrosek V, Blomstrom Lundqvist C, Borghi C, Cifkova R, Ferreira R, Foidart JM, Gibbs JSR, Gohlke-Baerwolf C, Gorenek B, Iung B, Kirby M, Maas AHEM, Morais J, Nihoyannopoulos P, Pieper PG, Presbitero P, Roos-Hesselink JW, Schaufelberger M, Seeland U, Torracca L, ESC Committee for Practice Guidelines, ESC guidelines on the management of cardiovascular diseases during pregnancy. The task force on the management of cardiovascular diseases during pregnancy of the European Society of Cardiology (ESC). Eur Heart J., 2011; 32(24): 3147-3197.

25. Regitz-Zagrosek V, Roos-Hesselink JW, Bauersachs J, Blomström-Lundqvist C, Cífková R, De Bonis M, Iung B, Richard JM, Kintscher U, Kranke P, Lang IM, Morais J, Pieper PG, Presbitero P, Price S, Rosano GMC, Seeland U, Simoncini T, Swan L, Warnes CA, ESC Scientific Document Group, ESC Guidelines on the management of cardiovascular diseases during pregnancy. Eur Heart J., 2018; 39(34): 3165-3241.

26. Richardson A, Shah S, Harris C, McCulloch G, Antoun $\mathrm{P}$, Anticoagulation for the pregnant patient with a mechanical heart valve, no perfect therapy: Review of guidelines for anticoagulation in the Pregnant Patient. Case Rep Cardiol., 2017; 2017: 3090273: 1-5.

27. Roos-Hesselink J, Baris L, Johnson M, De Backer J, Otto C, Marelli A, Jondeau G, Budts W, Grewal J, Sliwa K, Parsonage W, Maggioni AP, van Hagen I, Vahanian A, Tavazzi L, Elkayam U, Boersma E, Hall R, Pregnancy outcomes in women with cardiovascular disease: evolving trends over 10 years in the ESC Registry of Pregnancy and Cardiac disease (ROPAC). Eur Heart J., 2019; 40(47): 3848-3855.

28. Sessa M, Mascolo A, Callréus T, Capuano A, Rossi F, Andersen M, Direct-acting oral anticoagulants (DOACs) in pregnancy: new insight from VigiBase ${ }^{\circledR}$. Sci Rep., 2019; 9(1): 7236: 1-8. 
29. Sillesen M, Hjortdal V, Vejlstrup N, Sorensen K, Pregnancy with prosthetic heart valves - 30 years' nationwide experience in Denmark. Eur J Cardiothorac Surg., 2011; 40(2): 448-454.

30. Siu SC, Sermer M, Colman JM, Alvarez AN, Mercier LA, Morton BC, Kells CM, Bergin ML, Kiess MC, Marcotte F, Taylor DA, Gordon EP, Spears JC, Tam JW, Amankwah KS, Smallhorn JF, Farine D, Sorensen $S$, Cardiac Disease in Pregnancy (CARPREG) Investigators. Prospective multicenter study of pregnancy outcomes in women with heart disease. Circulation, 2001; 104(5): 515-521.

31. Sabău M, Tica $\mathrm{O}$, Chețan F, Țica $\mathrm{O}$, Comănescu A, Antal L, Mureșan M, Enăchescu V, Diaconu C, Bidian $\mathrm{C}$, Real life anticoagulant treatment for stroke prevention in patients with nonvalvular atrial fibrillation. Farmacia, 2020; 68(5): 912-918.

32. Steer PJ, Gatzoulis MA, Baker P. Consensus views arising from the $51^{\text {st }}$ study group: heart disease and pregnancy. In: Steer PJ, Gatzoulis MA, Baker P, editors. Heart disease and pregnancy. London: Royal College of Obstetricians and Gynaecologists Press 2006; 327-332.

33. Steinberg ZL, Dominguez-Islas CP, Otto CM, Stout KK, Krieger EV, Maternal and fetal outcomes of anticoagulation in pregnant women with mechanical heart valves. J Am Coll Cardiol., 2017; 69(22): 26812691.

34. Tang AW, Greer I, A systematic review on the use of new anticoagulants in pregnancy. Obstet Med., 2013; 6(2): 64-71.

35. Vahanian A, Baumgartner H, Bax J, Butchart E, Dion R, Filippatos G, Flachskampf F, Hall R, Iung B, Kasprzak J, Nataf P, Tornos P, Torracca L, Wenink A, Task Force on the Management of Valvular Hearth Disease of the European Society of Cardiology, ESC Committee for Practice Guidelines, Guidelines on the management of valvular heart disease: The Task Force on the Management of Valvular Heart Disease of the European Society of Cardiology. Eur Heart J., 2007; 28(2): 230-268.

36. Xu Z, Fan J, Luo X, Zhang WB, Ma J, Lin YB, Ma SH, Chen X, Wang ZP, Ou JS, Zhang X, Anticoagulation regimens during pregnancy in patients with mechanical heart valves: A systematic review and meta-analysis. Can J Cardiol., 2016; 32(10): 1248.e1-1248.e9.
37. Yinon Y, Siu SC, Warshafsky C, Maxwell C, McLeod A, Colman JM, Sermer M, Silversides CK, Use of low molecular weight heparin in pregnant women with mechanical heart valves. Am J Cardiol., 2009; 104(9): 1259-1263.

38. Zugravu C, Rașcu A, Oțelea MR, Macri A, Vitamin $\mathrm{D}$ from food and supplement intake in pregnancy. A pilot study. Farmacia, 2020; 68(1): 150-154.

39. Zoghbi WA, Chambers JB, Dumesnil JG, Foster E, Gottdiener JS, Grayburn PA, Khandheria BK, Levine RA, Marx GR, Miller Jr FA, Nakatani S, Quiñones MA, Rakowski H, Rodriguez LL, Swaminathan M, Waggoner AD, Weissman NJ, Zabalgoitia M, American Society of Echocardiography's Guidelines and Standards Committee, Task Force on Prosthetic Valves, American College of Cardiology Cardiovascular Imaging Committee, Cardiac Imaging Committee of the American Heart Association, European Association of Echocardiography, European Society of Cardiology, Japanese Society of Echocardiography, Canadian Society of Echocardiography, American College of Cardiology Foundation, American Heart Association, European Association of Echocardiography, European Society of Cardiology, Japanese Society of Echocardiography, Canadian Society of Echocardiography, Recommendations for evaluation of prosthetic valves with echocardiography and doppler ultrasound: a report from the American Society of Echocardiography's guidelines and standards committee and the task force on prosthetic valves, developed in conjunction with the American College of Cardiology Cardiovascular Imaging Committee, Cardiac Imaging Committee of the American Heart Association, the European Association of Echocardiography, a registered branch of the European Society of Cardiology, the Japanese Society of Echocardiography and the Canadian Society of Echocardiography, endorsed by the American College of Cardiology Foundation, American Heart Association, European Association of Echocardiography, a registered branch of the European Society of Cardiology, the Japanese Society of Echocardiography, and Canadian Society of Echocardiography. J Am Soc Echocardiogr., 2009; 22(9): 975-1014. 